\title{
Nebraska sedge (Carex nebraskensis Dewey): Phenology and life history at Tule Meadow, Sierra National Forest, California
}

\author{
RAYMOND D. RATLIFF AND STANLEY E. WESTFALL
}

\author{
Authors are range scientist and range technician (retired), Pacific Southwest Research Station, USDA Forest \\ Service, 2081 E. Sierra Ave., Fresno, Calif. 93710.
}

\begin{abstract}
To better understand shoot development and population dynamics of Nebraska sedge (Carex nebraskensis Dewey), a valuable mountain meadow forage species, 766 shoots were tagged and studied at Tule Meadow, on the Sierra National Forest, California. $A$ key to its vegetative and reproductive phenologic stages was developed. New shoots emerged throughout the growing season, but mostly in spring. Spring shoots reached the mature vegetative stage before autumn. Late summer and autumn shoots overwintered in juvenile vegetative stages. About $3 \%$ of each year's cohort of shoots died as juveniles. Early emerging shoots passed as least 1 winter but late emerging shoots passed at least 2 winters before flowering. Among shoots reaching the mature vegetative stage, $60 \%$ eventually flowered and died. An average of $90 \%$ of the vegetative shoots alive each autumn survived winter. A few shoots remained vegetative and had long lives -1 shoot was still alive after 7.5 years. Vegetative shoots (those not becoming reproductive) of the 1980 and 1981 cohorts lived an average of $599 \pm 50$ days. Shoots that became reproductive (flowered) lived an average of $631 \pm 17$ days, and time from shoot emergence to culm elongation averaged $501 \pm 18$ days. Nebraska sedge appears well adapted to grazing by having long-lived vegetative shoots that can produce new herbage for several years. Nevertheless, grazing management should strive to maximize the numbers of shoots in spring because they are the ones that can flower the next season.
\end{abstract}

Key Words: Sierra Nevada, meadow, plant growth, demography, life span

A valued forage species on many mountain meadows in the western United States, Nebraska sedge (Carex nebraskensis Dewey) is palatable to cattle and horses. It withstands frequent and heavy grazing during summer and autumn. Its distinctive silvery bluegreen foliage is evident when a shoot emerges. New shoots arise throughout the growing season from strongly developed root stocks or tillers. A single culm arises at the shoot center and bears 1 or 2 staminate spikes above 2 to 5 pistillate spikes (Hermann 1970). Culms can reach 1.2-m high, but heights of 40-60 cm are typical.

The range of Nebraska sedge extends from South Dakota and Kansas to New Mexico, California, and northward to British Columbia (Hermann 1970). In California, Nebraska sedge grows in wetlands from near sea level to $3,200 \mathrm{~m}$ (Munz and Keck 1959). It is most common in the ponderosa pine (Pinus ponderosa Dougl.) and fir (Abies)-lodgepole pine (Pinus murrayana Balf.) zones of the Sierra Nevada and Cascade Mountains, where it frequently dominates meadows. The species is found on level or

\footnotetext{
The authors wish to thank the Kings River Ranger District, Sierra National Forest, for its cooperation in this study and the Pacific Gas and Electric Company for providing weather records from Wishon Dam.

Manuscript accepted 13 May 1991.
}

nearly level sites where water flows over the surface in spring but does not pond. Nearly pure stands grow where overflow water is about 10 -cm deep.

Basic information about Nebraska sedge and sites where it grows is scant. Livestock select this species at about the same time each year. Therefore, too heavy, too frequent, or untimely grazing could damage the stand, alter species composition, and lower site productivity. Information, therefore, is needed to assure proper management of this important meadow species. In 1979, we started a series of studies of Nebraska sedge at Tule Meadow, Sierra National Forest, in central California. Completed studies have been reported on life history (Ratliff 1983), carbohydrate levels (Steele et al. 1984), dry-year grazing (Ratliff and Westfall 1987), and biomass trends (Ratliff and Westfall 1988).

This paper reports findings on shoot phenology and life history of Nebraska sedge in a study designed to better understand shoot development and population dynamics.

\section{Materials and Methods}

\section{Study Site}

Tule Meadow, the study site, is accessible most of the year. At 2,170-m elevation, it lies in a swale formed by lateral moraines (Wood 1975). Surface water is present much of the time. Beneath the surface, organically rich top soil reaches depths of 90 to $120 \mathrm{~cm}$. Soil texture ranges from sand to silt loam. Inorganic, gleyed material extends to $275 \mathrm{~cm}$.

The site selected is typical of the lotic, Nebraska sedge series (Ratliff 1982 and 1985). Other species prevalent on the site include beaked sedge (Carex rostrata (Stokes) and tufted hairgrass (Deschampsia caespitosa [L.] Beauv.). Soil is typically that of Nebraska sedge sites in the Sierra Nevada. At $10 \mathrm{~cm}$ to $20 \mathrm{~cm}$, soil texture is loam, reaction is strongly acid, and organic matter is over $20 \%$.

\section{Climate}

At Tule Meadow, as is usual for the Sierra Nevada, precipitation comes mostly as snow in autumn and winter. Summers are warm and dry with occasional thunder storms.

Precipitation and air temperature records used were taken at Wishon Dam, 3 miles from Tule Meadow. Identical values would occur only by chance; nevertheless, general trends in weather should be the same. For example, at Tule Meadow, snow on the study site was $150-\mathrm{cm}$ deep on 10 April 1980, and lasted until late May. At Wishon Dam snow was 46-cm deep on the 10th and was gone by the end of April. The following year, 1981, there was no snow on the ground on at Wishon Dam on 10 April. At Tule Meadow snow was gone and water was 5 to $10-\mathrm{cm}$ deep on 29 April.

Air temperatures at Wishom Dam were highest (mean maxi- 
mum $=25.2^{\circ} \mathrm{C}$ and mean minimum $=10.1^{\circ} \mathrm{C}$ ) in August, and were lowest (mean maximum $=7.2^{\circ} \mathrm{C}$ and mean minimum $=-3.8^{\circ} \mathrm{C}$ ) in January. Over $90 \%$ of the annual precipitation fell from October thru April. During the study, precipitation varied widely (Fig. 1), from $164 \%(1982-83)$ to only $46 \%(1986-87)$ of the average $147 \pm$ $43 \mathrm{~cm}$ ). The snowpack was usually deepest in February, averaging $94 \mathrm{~cm}$ that month.

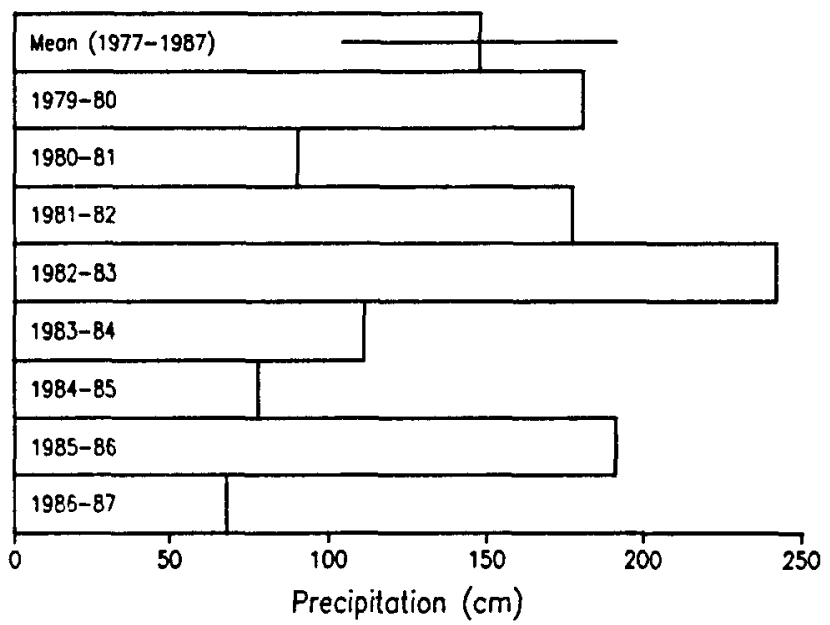

Fig. 1. Mean and yeurly precipitation (September through August) at Wishon Dam, Sierra National Forest, California. The whisker represents the $95 \%$ confidence interval for the mean.

At Tule Meadow, surface water was present through summer and autumn of 1983 and until the end of July 1980 and 1982. In contrast, surface water disappeared by mid-June in 1985 and by the end of June in 1981 and 1984.

\section{Sampling}

Although a Nebraska sedge shoot is not an entity of itself, it was selected as the unit of observation. A "genet" is the total biologic or genotypic individual (Alexeev 1988). An individual of Nebraska sedge is thus composed of several shoots, including shoot clumps. A genet, like a shoot, passes through stages of development and eventually dies; and 2 genets, like 2 shoots, may be in different stages. By studying genets, we can learn how different species vary in their life cycles, but studies require careful, destructive sampling. Also, land managers cannot efficiently identify and observe genets in the field. Individual shoots, on the other hand, are easy to identify and observe with the plants and substrate left intact.

The experimental design used was a simple random sample from a finite population. An exclosure built on the site prevented grazing disturbance. Within the exclosure, a $10-\times 0.5-\mathrm{m}$ study area was divided into 40 possible plots. Ten of these plots were randomly selected and staked.

Each plot was $25 \times 50 \mathrm{~cm}$, which was large enough to assure it contained several shoots of Nebraska sedge. The plots were small enough to assure that we could detect new shoots as well as older ones.

A total of 766 shoots of Nebraska sedge found in the 10 plots were identified by numbered plastic tags tied around the shoot bases with stainless steel wire. The pre-1980 cohort comprised 279 shoots tagged in early December 1979 (Ratliff 1983). From 22 May 1980 to 4 November 1981 , we tagged 487 new shoots $(1980$ cohort $=$ 254 and 1981 cohort $=233$ ) that emerged in the plots.

We recorded individual shoot phenology from 1980 to 1987. Shoots were observed from spring (as soon as the study area was clear of snow) to autumn (after vegetative shoots were quiescent and reproductive shoots were senescent or dead). Frequency of observation was biweekly through mid July 1984. Thereafter, (due to lower shoot numbers), phenology was observed about once a month. We observed the last few remaining shoots on 21 May 1987.

\section{Analyses}

Although this paper includes the shoots originally tagged as part of the total study population, the focus is the 1980 and 1981 cohorts. We know when they were first observed, if and when they became reproductive, and when they died. We do not know, however, when the shoots tagged in December 1979 emerged.

Because there were no experimental treatments as such, the approach used to analyze the information was to compute $95 \%$ confidence intervals (CI). Unless stated otherwise, $\mathrm{CI}$ were based on plot values $(\mathrm{N}=10)$. CI were computed on: (a) proportions of the shoot population in vegetative and reproductive stages on selected dates throughout the study period using all shoots in a plot; (b) shoot emergence rates, times from emergence to specific phenologic stages, survival, and longevity for the 1980 and 1981 cohorts; (c) differences between dates within cohorts and differences between cohorts; and (d) air temperatures, based upon the number of days in spring, spring-summer, summer-autumn, and autumn.

\section{Results and Discussion}

\section{Phenology}

Nebraska sedge produces culmless vegetative shoots (Ratliff 1983). Description of a shoot's phenologic stage was therefore dependent on whether elevation of its apical meristem could be detected. Vegetative shoot stages recognized were juvenile, mature, and overwintered. Reproductive shoot stages recognized were elongation, flowering, seed ripening, and senescence. A dead stage was included for demographic purposes.

Key

A. Shoots with live (green) tissue at least at the center.

B. Shoots vegetative, leaves all basal, and culm elongation not evident.

C. Previous season's leaf sheaths not present, 3 or less leaves unfolded, and shoot base not thick and spongyJuvenile vegetative stage.

CC. Previous season's leaf sheaths present and/or shoot base thickened and spongy.

D. Previous season's leaf sheaths not present.-Mature vegetative stage to quiescent state.

DD. Previous season's leaf sheaths present.-Overwintered vegetative stage.

BB. Shoots reproductive, inflorescence showing and/or culm elongation evident.

C. Anthers not showing.-Elongation stage.

CC. Anthers and stigmas showing.

D. Anthers not reflexed.-Flowering stage.

DD. Anthers reflexed.

E. Spikes still green or mostly green.-Seed ripening stage.

EE. Spikes brown or mostly brown, leaves yellowing.Senescent stage.

AA. Green tissue absent.-Shoot dead.

In the earliest detectable stage, a shoot of Nebraska sedge looked like the tip of an awl. That form, as reported for Carex gracilis Curt (Soukupova 1988), enabled the shoot to break the surface. The shoot was considered juvenile until more than 3 leaves had unfolded and thickening of its base was evident-producing a spongy feeling when gently squeezed. We do not know if that characteristic indicated formation of axillary buds. We assumed 
that the shoot was still a reproductive juvenile.

When over $50 \%$ of the leaf area of a vegetative shoot was yellowing, the shoot was designated as becoming quiescent. An overwintering, mature vegetative Nebraska sedge shoot was characterized by old leaf sheaths and a core of green tissue. In spring, such a shoot put out new leaves, as did juvenile ones. It did not repeat the earliest stages, however, and remained classed as overwintered and vegetative until it became reproductive or died.

A shoot's entrance into the reproductive stages was evidenced by elevation of the apical meristem. Elevation was first observed in early spring as a convex structure at the shoot center. This structure quickly elongated into an oval shape, followed by a fully visible inflorescence with no anthers. Full bloom occurred when the staminate spikes had about $50 \%$ of the anthers showing and many stigmas were showing on the pistillate spikes.

When the anthers reflexed but many stigmas were still present and the spikes were still green, a shoot had entered the seedripening stage. Browning of the spikes and yellowing leaves with a still-green culm signaled the onset of senescence. A shoot was considered dead when no green leaf, culm, or inner core tissue was present (Bedford et al. 1988, Hultgren 1988).

\section{Weather}

New shoots of Nebraska sedge rose above the meadow surface from early spring until reproductive shoots reached advanced senescence in autumn (Table 1). Most shoots emerged while sur-

Table 1. Emergence of Nebraska sedge (Carex nebraskensis) shoot cohorts and water depths at Tule Meadow, in relation to daily air temperatures at Wishon Dam, Sierra National Forest, California.

\begin{tabular}{|c|c|c|c|c|}
\hline \multirow[b]{2}{*}{ Variable } & \multicolumn{4}{|c|}{ Cohort Emergence Periods ${ }^{1}$} \\
\hline & Spring & $\begin{array}{l}\text { Spring- } \\
\text { summer }\end{array}$ & $\begin{array}{l}\text { Summer- } \\
\text { autumn }\end{array}$ & Autumn \\
\hline \multicolumn{5}{|c|}{ Cohort emergence (1980) } \\
\hline $\begin{array}{l}\text { Shoots } \mathrm{m}^{-2} \text { day }^{-1} \\
\text { Percentage }\end{array}$ & $\begin{array}{c}2.2 \pm 0.7^{2} \\
44.9\end{array}$ & $\begin{array}{l}1.1 \pm 0.5 \\
22.8\end{array}$ & $\begin{array}{c}0.7 \pm 0.4 \\
20.1\end{array}$ & $\begin{array}{l}0.6 \pm 0.3 \\
12.2\end{array}$ \\
\hline Water depths (cm) & 12.3 & 5.8 & 0.7 & 0.2 \\
\hline \multicolumn{5}{|c|}{ Air temperatures $\left({ }^{\circ} \mathrm{C}\right.$ ) } \\
\hline Maximum & $16.8 \pm 1.7$ & $25.7 \pm 1.3$ & $22.8 \pm 0.9$ & $14.1 \pm 1.8$ \\
\hline Minimum & $4.2 \pm 1.2$ & $11.4 \pm 1.1$ & $7.8 \pm 0.7$ & $1.5 \pm 1.1$ \\
\hline Mean & $10.1 \pm 1.4$ & $18.6 \pm 1.1$ & $15.3 \pm 0.7$ & $7.8 \pm 1.4$ \\
\hline \multicolumn{5}{|c|}{ Cohort emergence (1981) } \\
\hline Shoots $\mathrm{m}^{-2}$ day $^{-1}$ & $2.7 \pm 0.7$ & $1.1 \pm 0.4$ & $0.5 \pm 0.2$ & $0.6 \pm 0.4$ \\
\hline Percentage & 40.3 & 25.3 & 19.7 & 14.6 \\
\hline Water depths (cm) & 11.4 & 5.5 & 0.0 & 0.1 \\
\hline \multicolumn{5}{|c|}{ Air temperatures $\left({ }^{\circ} \mathrm{C}\right)$} \\
\hline Maximum & $14.8 \pm 1.8$ & $22.3 \pm 1.2$ & $24.6 \pm 0.6$ & $12.2 \pm 1.8$ \\
\hline Minimum & $3.0 \pm 1.1$ & $9.0 \pm 0.9$ & $12.6 \pm 0.5$ & $2.8 \pm 1.4$ \\
\hline Mean & $8.9 \pm 1.3$ & $15.7 \pm 0.9$ & $18.6 \pm 0.5$ & $7.5 \pm 1.4$ \\
\hline
\end{tabular}

1980 cohort: Spring-22 May to 2 July, spring-summer-2 July to 13 August, summer-autumn-13 August to 8 October, autumn-8 October to 20 November. 1981 cohort: Spring-29 April to 27 May, spring-summer-27 May to 8 July, summerautumn-8 July to 23 September, autumn-23 September to 4 November.

$295 \%$ confidence intervals.

face water was present and temperatures were relatively low. In both 1980 and 1981 , more than $40 \%$ of the shoots emerged while surface water depths exceeded $11 \mathrm{~cm}$ and daily mean temperatures averaged about $10^{\circ} \mathrm{C}$. With daily mean temperatures averaging $7^{\circ}$ $\mathrm{C}$ to $9^{\circ} \mathrm{C}$ warmer, surface water was gone by 13 August 1980 and 8 July 1981. Another 23\% (1980) and 25\% (1981) of the year's cohort of shoots had been added by then, and $66 \%$ of each cohort was present.

Another $20 \%$ of each cohort emerged under relatively dry, warm weather of the summer-autumn period (Table 1). Daily mean temperatures averaged near or above $16^{\circ} \mathrm{C}$ to early October 1980 , and to the last week of September 1981. With rain, water rose above the surface for a few days in September 1980. Conditions were otherwise dry.

The final $12 \%$ to $15 \%$ of the cohorts emerged under dry, cool weather. Daily mean temperatures averaged near $7^{\circ} \mathrm{C}$ from midOctober and late September to the last sampling dates on 20 November 1980 and 4 November 1981 . Temperatures were too low or days too short or both for many shoots to emerge during the last sampling interval.

Culm elongation, flowering, and seed ripening tended to advance as mean daily temperatures increased. Senescence started when temperatures declined. Mean daily temperatures at Wishon Dam for the 2 weeks immediately preceding peaks of the various phenologic stages averaged $8.7^{\circ} \mathrm{C}$ (vegetative), $13.0^{\circ} \mathrm{C}$ (elongation), $16.7^{\circ} \mathrm{C}$ (flowering), $17.2^{\circ} \mathrm{C}$ (seed ripening), and $14.1^{\circ} \mathrm{C}$ (senescence).

Total precipitation and the snowpack affected temperatures and timing of phenologic events (Fig. 2). Culm elongation was well along on 10 June, and the shoots were senescent by 2 September in 1981 (a dry year); but culms did not elongate before $13 \mathrm{July}$, and shoots were not senescent before 2 November in 1983 (a wet year).

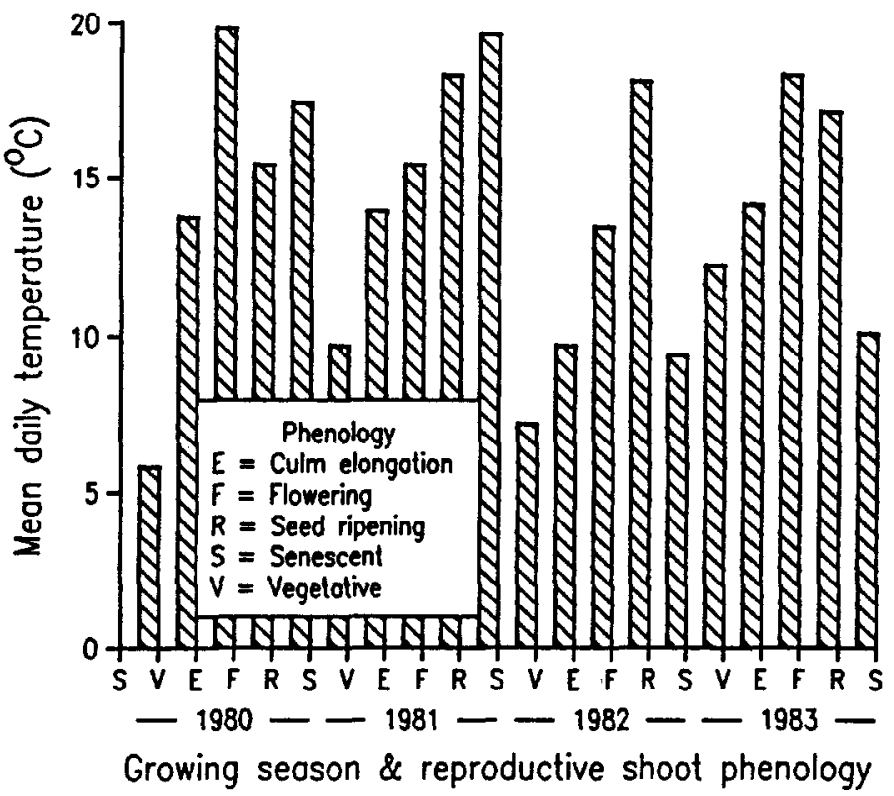

Fig. 2. Relationship of Nebraska sedge reproductive shoot phenologic stages at Tule Meadow to mean daily air temperatures at Wishon Dam, Sierra National Forest, Calif.

The last day in 1981 that the snow pack was $30 \mathrm{~cm}$ deep or more was 13 February. In 1983 the snowpack was still $30-\mathrm{cm}$ deep on 11 May-3 months later than in 1981.

On average, the last date in spring when all shoots were still vegetative was 1 June. The highest percentage of shoots were in culm elongation stages on 25 June, in flowering stages on $23 \mathrm{July}$, and in seed ripening stages on 17 August. Generally, all reproductive shoots were in senescent stages or were dead by 5 October.

\section{Life History \\ Shoot Development}

Shoot development from the juvenile to the mature vegetative stages occurred mainly in spring and summer. A few shoots, however, matured in autumn. Development to the reproductive stage occurred only in spring and early summer.

Once a shoot emerged from the substratum, 70 to 96 days (average) were required for it to develop to the mature vegetative stage (Table 2). Some shoots reached that stage in 24 to 32 days 
Table 2. Shoot development of Nebraska sedge cohorts, 1980 and 1981, at Tule Meadow, Sierra National Forest, California.

\begin{tabular}{lrr}
\hline \hline \multirow{2}{*}{$\begin{array}{l}\text { Phenologic stage of } \\
\text { shoot development }\end{array}$} & \multicolumn{2}{c}{ Cohort } \\
\cline { 2 - 3 } & \multicolumn{1}{c}{ Days from emergence } \\
Mature vegetative & $28 \pm 4$ & $31 \pm 4$ \\
Season of emergence & & \\
The following spring & $247 \pm 10$ & $267 \pm 17$ \\
From emergence & $30 \pm 3$ & $36 \pm 7$ \\
After winter & $94 \pm 22$ & $90 \pm 20$ \\
Average for all shoots & $475 \pm 25$ & $526 \pm 38$ \\
Reproductive &
\end{tabular}

1 Days from shoot emergence to first observation of mature vegetative \& reproductive stages, $95 \%$ confidence intervals.

(1980 cohort) and 27 to 35 days ( 1981 cohort) during their season of emergence; the between-cohort difference averaged $3.0 \pm 6.4$ days. Other shoots did not mature until the following spring -8 to 9 months-after their emergence.

More than $60 \%$ of each cohort lived to become sexually reproductive. Reproductive organs appeared 1.2 to 1.4 years after emergence (1980 cohort) and 1.3 to 1.6 years after emergence (1981 cohort). The between cohort difference of $50.9 \pm 50.0$ days may be related to differences in precipitation and temperature. No shoot became reproductive the season it emerged. All shoots passed at least 1 winter in the mature vegetative stage. About $35 \%$ of the shoots in each cohort became reproductive during their second season. Another $26 \%$ of each cohort became reproductive in their third season.

\section{Shoot Death}

We do not know how old the shoots of the pre- 1980 cohort were in December 1979. Nevertheless, the percentages of shoots each autumn and spring in each of the 3 cohorts followed the same general pattern (Fig. 3).

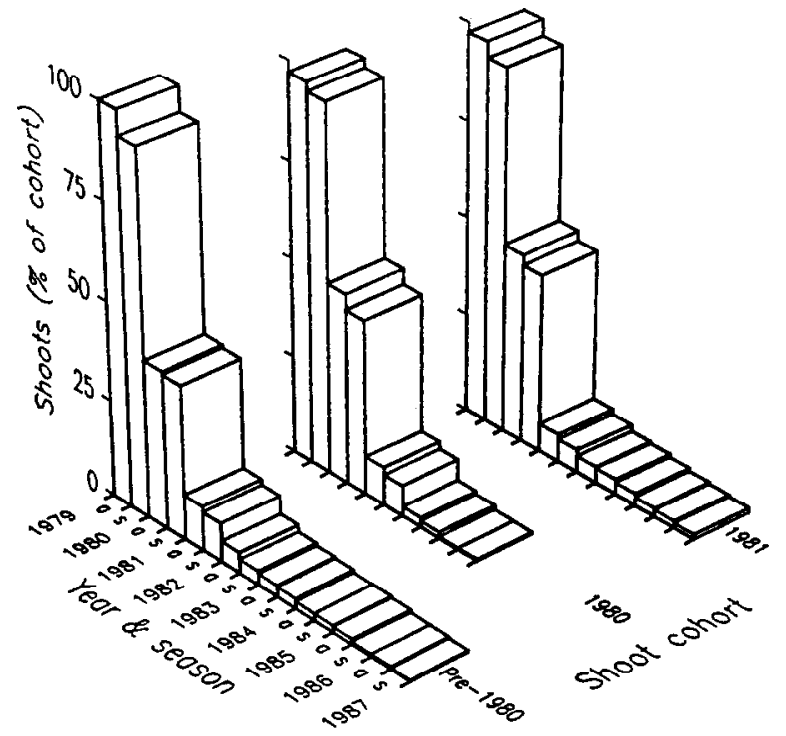

Fig. 3. Relative sizes of 3 Nebraska sedge cohorts at Tule Meadow, Sierra National Forest, Calif., by year and season ( $a=$ autumn and $s=$ spring). Combined reproductive and vegetative shoot percentages are represented by the columns for spring. Columns for autumn represent only vegetative shoots. Autumn-spring steps indicate winter losses.

Major losses from each cohort occurred when reproductive shoots died in autumn and winter, and at the end of the fourth year only about $4.5 \%$ of each cohort remained. For all shoots, death occurred 1.6 to 1.8 years after emergence (1980 cohort) and 1.6 to 2.0 years after emergence ( 1981 cohort); the between cohort differ- ence averaged $1.9 \pm 2.8$ months. Only $3.2 \% \pm 2.2 \%$ of the 1980 cohort and $2.6 \% \pm 2.0 \%$ of the 1981 cohort died before their first winter. First-winter deaths accounted for another $2.4 \% \pm 1.9 \%$ (1980) and $4.3 \% \pm 2.6 \%$ (1981) of the cohorts. Second-winter deaths were of the same magnitude and averaged $3.3 \%$ of the cohorts. Third-winter deaths averaged 1.6\%. Spring-throughautumn deaths of vegetative shoots accounted for about $10.5 \%$ of each cohort in both the second and third years. Deaths between the first and second autumns (reproductive shoots included) accounted for $48.0 \% \pm+6.1 \%$ of the 1980 cohort and $49.4 \% \pm 6.4 \%$ of the 1981 cohort. Between the second and third autumn, another $40 \%$ of each cohort died.

Less than $3 \%$ of the shoots in the 1980 and 1981 cohorts died in juvenile stages. Juvenile shoots that survived longest emerged in autumn (Table 3). For both cohorts combined, 9.4\% of 149 juvenile shoots present the first autumn died during winter or early the next spring.

Table 3. Shoot longevity of Nebraska sedge cohorts, 1980 and 1981, at Tule Meadow, Sierra National Forest, California.

\begin{tabular}{lccccc}
\hline \multirow{2}{*}{$\begin{array}{l}\text { Phenologic stage } \\
\text { at shoot death }\end{array}$} & \multicolumn{2}{c}{1980 Cohort } & & \multicolumn{2}{c}{1981 Cohort } \\
\cline { 2 - 3 } \cline { 5 - 6 } \cline { 5 - 6 } & Percent & Longevity & & Percent & Longevity \\
\hline Juvenile vegetative & 2.8 & $14-287^{2}$ & & 2.2 & $14-294$ \\
Mature vegetative $^{3}$ & 34.6 & $651 \pm 118^{4}$ & & 36.9 & $672 \pm 193$ \\
Reproductive & 62.6 & $609 \pm 25$ & & 60.9 & $652 \pm 35$ \\
\hline
\end{tabular}

IDays since emergence (first observation) to death of the shoot.

2Minimum and maximum.

Includes overwintered, vegetative shoots living on 21 May 1987.

$495 \%$ confidence intervals.

More than a third of each shoot cohort died after reaching the mature vegetative stage but without becoming reproductive. Such shoots lived an average of 1.5 to 2.1 years (1980 cohort) and 1.3 to 2.4 years (1981 cohort); the between-cohort difference averaged $0.06 \pm 0.55$ years. A few shoots developed and died quickly -42 days was the shortest record. A few shoots lived and produced new foliage for several years. The longest record for the 1980 and 1981 cohorts was 5.8 years-the shoot was still alive on 21 May 1987 . One shoot of the pre-1980 cohort was still alive after at least 7.5 years.

Shoots reaching the reproductive stage lived for averages of 1.6 to 1.7 years (1980 cohort) and 1.7 to 1.9 years (1981 cohort); the between cohort difference averaged $0.12 \pm 0.14$ years. Their leaves retained some green tissue 4 to 4-1/2 months after reproductive structures were first evident.

\section{The Population \\ Structure}

Between-plot variation in proportions of shoots in various stages was high. As a result the confidence intervals (Fig. 4) suggested little difference within and between seasons in the percentages of shoots in juvenile, mature vegetative, and reproductive stages. Also, the study population was complete at the end of 1981 , and data for 1982 reflect the continual decline in shoot numbers. The peak for mature vegetative shoots in 1982, for example, suggest that new shoots were not added to the total. Nevertheless, general trends were apparent.

In 1980 and 1981 , more than $60 \%$ of the total live shoot population was in vegetative stages at all times. Just after snow melt all shoots appeared to be in vegetative stages with juveniles averaging $27 \%$ and mature shoots $73 \%$ of the shoots then alive. The peak for juveniles in 1981 was caused by slightly higher numbers of early shoots and winter and early spring losses of mature vegetative shoots. With culm elongation, mature vegetative shoot percentages dropped markedly; they increased as juvenile shoots matured 

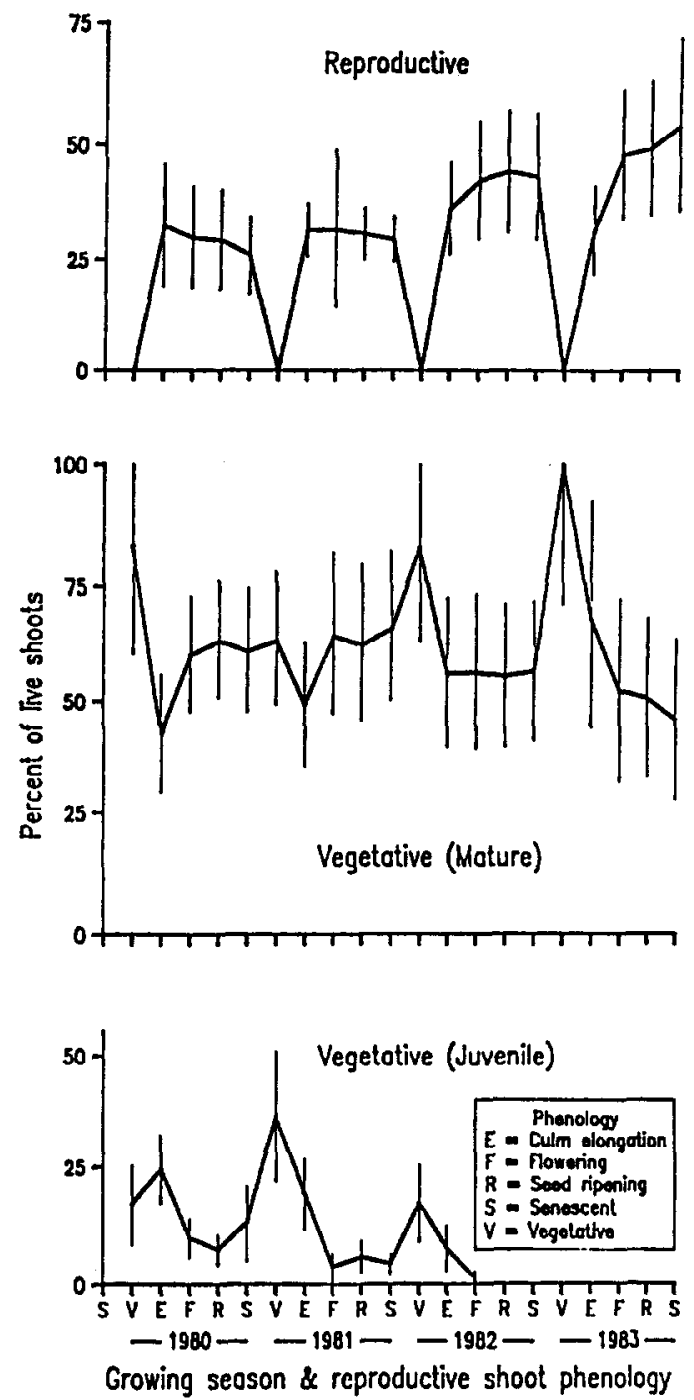

Fig. 4. Percentages of Nebraska sedge juvenile, mature, and reproductive shoots at selected reproductive shoot phenologic stages during 4 growing seasons at Tule Meadow, Sierra National Forest, Calif. The whiskers around the percentages represent the $95 \%$ confidence intervals.

and reproductive shoots flowered. Percentages of mature vegetative shoots dipped at or near senescence reflecting emergence of late shoots. At flowering, proportions of shoots averaged $6.5 \%$ (juvenile), $62.6 \%$ (mature vegetative), and $30.9 \%$ (reproductive). While a few of them died, the gradual decline in reproductive shoot percentages to senescence reflects low but continual emergence of new shoots.

\section{Dynamics}

The rates of shoot emergence in spring, spring-summer, summerautumn, and autumn periods were:

\section{Emergence period}

Spring

Spring-summer

Autumn
Summer-autumn

Seasonal rates of shoot emergence were $1.1 \pm 0.3$ shoots $\mathrm{m}^{-2}$ day $^{-1}$ in 1980 and $1.0 \pm 0.3$ shoots $\mathrm{m}^{-2}$ day $^{-1}$ in 1981 . Rates were greatest the month after plots were clear of snow-2.7 \pm 1.0 shoots $\mathrm{m}^{-2} \mathrm{day}^{-1}$ in 1980 and $2.7 \pm 0.7$ in 1981. For the remainder of each

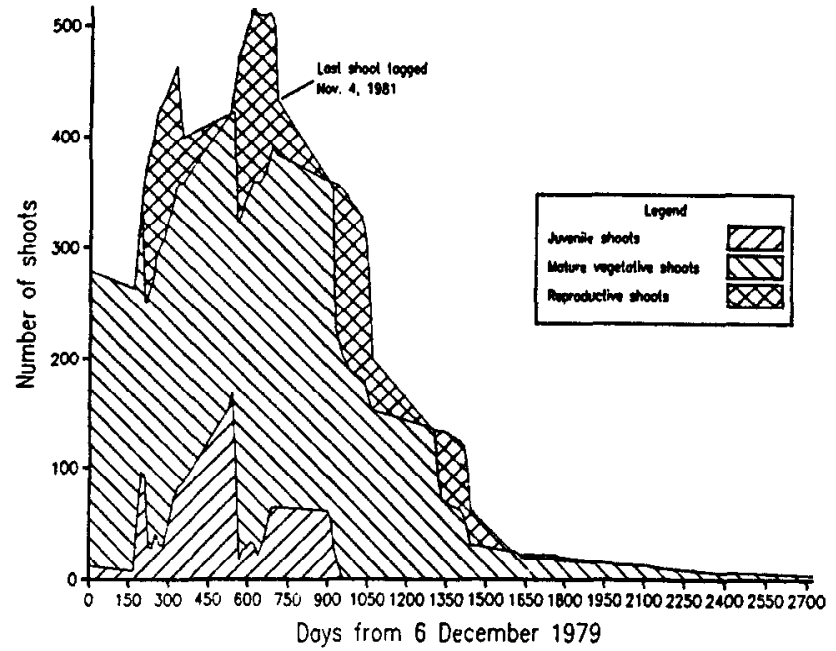

Fig. 5. Life history of the Nebraska sedge study population at Tule Meadow, Sierra National Forest, Callf., December 1979-May 1987.

season, emergence averaged 0.8 shoot $\mathrm{m}^{-2} \mathrm{day}^{-1}(1980)$ and 0.7 (1981).

Overwinter survival of vegetative Nebraska sedge shoots, regardless of age, was high (Fig. 5). Average percentages of shoots alive at the last observation the first 4 autumns (juveniles included) that survived winter were as follows:

\begin{tabular}{lcccc} 
Winter & \multicolumn{3}{c}{$\begin{array}{c}\text { Cohort } \\
\text { Pre-1980 }\end{array}$} & $\frac{1980}{1981}$ \\
\cline { 1 - 1 } First & $93.1 \pm 4.8$ & $97.1 \pm 2.9$ & $96.1 \pm 2.8$ \\
Second & $97.8 \pm 5.0$ & $88.5 \pm 7.9$ & $93.7 \pm 6.6$ \\
Third & $94.6 \pm 7.0$ & $80.2 \pm 26.9$ & $86.1 \pm 23.3$ \\
Fourth & $63.1 \pm 41.7$ & $70.0 \pm 55.5$ & $91.7 \pm 26.5$
\end{tabular}

During the study, 500 shoots (65.3\% of our study populationall cohorts combined) became reproductive. Average percentages of shoots alive on the first spring observations (juveniles included) becoming reproductive were highest the third growing season:

\begin{tabular}{lcccc} 
Season & \multicolumn{3}{c}{$\begin{array}{c}\text { Cohort } \\
\text { Pre-1980 }\end{array}$} & $\frac{1980}{1981}$ \\
\cline { 2 - 5 } Second & $45.8 \pm 12.0$ & $41.2 \pm 10.3$ & $39.4 \pm 11.5$ \\
Third & $63.4 \pm 10.7$ & $62.0 \pm 10.3$ & $62.2 \pm 15.2$ \\
Fourth & $5.8 \pm 8.9$ & $25.0 \pm 38.7$ & $4.2 \pm 10.7$ \\
Fifth & 0.0 & $50.0 \pm 91.8$ & 0.0
\end{tabular}

Differences between the second and third seasons were $17.7 \% \pm$ $17.0 \%$ (pre- 1980 cohort), $20.9 \% \pm 11.9 \%$ (1980 cohort), and $22.9 \pm$ $11.5 \%$ (1981 cohort).

Reproductive shoots looked like overwintered vegetative shoots on the first 1 or 2 observations in spring. At full flowering, reproductive shoot-to-vegetative shoot ratios were:

\begin{tabular}{lccc}
\multicolumn{2}{l}{ Flowering date } & & Ratio \\
\cline { 1 - 1 } 30 July & 1980 & & $1: 2.1$ \\
24 June & 81 & & $1: 2.1$ \\
14 July & 82 & & $1: 1.4$ \\
10 Aug. & 83 & $1: 1.1$ \\
27 June & 84 & $1: 6.3$
\end{tabular}

Ratios for 1982 and 1983 reflect the fact that new shoots were no longer being added to the population (Fig. 5). The ratio for 1984 suggests that older shoots of a population have reduced capacity to flower. While involving only 22 shoots, none of the 19 vegetative shoots became reproductive by the end of the study. 


\section{Summary and Conclusions}

How long a particular Nebraska sedge individual may live is not known. For other Carex species, estimated genet life spans have ranged from under 10 years to 100 years or more (Alexeev 1988). Individual shoots of Nebraska sedge, however, remain vegetative for a year or more after emergence. Some live for several years, and most vegetative shoots present in autumn survive winter. Winter survival is also high in beaked sedge (Bernard 1974 and 1976).

Life spans of Nebraska sedge reproductive and vegetative shoots both averaged around 600 days and were within expected ranges. In temperate zones, shoot life spans of 1 or 2 years are typical (Alexeev 1988, Bernard 1976, Bernard and MacDonald 1974, Soukupova 1988). In arctic and alpine zones, individual shoots of some species may reach ages of 5 to 7 years (Alexeev 1988). The life span of beaked sedge shoots at lower latitudes (about 2 years) increased to 3 years or more at subarctic latitudes (Hultgren 1988). Specific study would be needed to determine if similar longevity changes occur in Nebraska sedge in response to elevation or latitude or both.

About $60 \%$ of the shoots of Nebraska sedge may eventually produce flowers, and some individuals may have a long life cycle (Soukupova 1988); that is, they start from seed, develop to become generative, spread vegetatively, and live for many years. Production of viable seed and seedlings, however, is rare in many sedges (Alexeev 1988), and growth and spread is mainly by vegetative means through the short life cycle when new individuals develop from mature vegetative shoots (Soukupova 1988).

Nebraska sedge population stability and shoot densities may largely depend upon water depth in spring. Most of the shoots emerged while surface water was present. Hormay (1943) observed that constancy of moisture conditions over a series of years governs species establishment and stability in meadows. Where water depths varied yearly, beaked sedge shoot density varied widely; but where water depths varied little from year to year, density was relatively constant (Hultgren 1988).

With high shoot longevity and winter survival, Nebraska sedge is ready to start photosynthesis when temperatures rise sufficiently in spring. As a result, spring growth and population stability do not depend totally on a new shoot cohort developing each year.

The primordia of the culmless vegetative shoots are not readily accessible to the grazing animal, and leaf replacement is not totally dependent on shoot replacement after grazing. With their primordia transformed for flowering, the source of new leaves is removed, and reproductive shoots (grazed or ungrazed) will die before the following spring.
Nebraska sedge can withstand grazing well because of high shoot longevity coupled with culmless vegetative shoots and vegetative reproduction. With conservative use by livestock or wildlife or both, therefore, the health of Nebraska sedge populations should be a minor concern. Nevertheless, managers need to maintain maximum spring shoot emergence. Spring shoots are those of the year's cohort capable of flowering the next season. Also, they are the most numerous, and over a period of years low numbers of spring shoots may reduce the population.

\section{Literature Cited}

Alexeev, Yu. E. 1988. Ontogenesis in Carex species. Aquat. Bot. 30:39-48. Bedford, B.L., N.R. Rappaport, and J.M. Bernard. 1988. A life history of Carex lasiocarpa Enrh. ramets. Aquat. Bot. 30:63-80.

Bernard, J.M. 1974. Seasonal changes in standing crop and primary production in a sedge wetland and an adjacent dry old-field in central Minnesota. Ecology 55:350-359.

Bernard, J.M. 1976. The life history and population dynamics of shoots of Carex rostrata. J. Ecol. 64:1045-1048.

Bernard, J.M., and J.G. MacDonald, Jr. 1974. Primary production and life history of Carex lacustris. Can. J. Bot. 52:117-123.

Hermann, F.J. 1970. Manual of the carices of the Rocky Mountains and Colorado Basin. USDA Agr. Handb. 374, Washington, D.C.

Hormay, A.L. 1943. Observations on species composition in northeastern California meadows as influenced by moisture supply. USDA, Forest Serv., California Forest and Range Exp. Sta., Berkeley, Calif.

Hultgren, A.B.C. 1988. A demographic study of aerial shoots of Carex rostrata in relation to water level. Aquat. Bot. 30:81-93.

Munz, P.A., and D.D. Keck. 1959. A California flora. University of California Press, Berkeley.

Ratlif, R.D. 1982. A meadow site classification for the Sierra Nevada, California. Gen. Tech. Rep. PSW-60. USDA, Forest Serv., Pacific Southwest Forest and Range Exp. Sta., Berkeley, Calif.

Ratlif, R.D. 1983. Nebraska sedge (Carex nebraskensis Dewey): Observations on shoot life history and management. J. Range Manage. 36:429-430.

Ratliff, R.D. 1985. Meadows in the Sierra Nevada of California: state of knowledge. Gen. Tech. Rep. PSW-84. USDA, Forest Serv., Pacific Southwest Forest and Range Experiment Station, Berkeley, Calif.

Ratliff, R.D., and S.E. Westfall. 1987. Dry-year grazing and Nebraska sedge (Carex nebraskensis). Great Basin Natur. 47:422-426.

Ratliff, R.D., and S.E. Westfall. 1988. Biomass trends in a Nebraska sedge meadow, Sierra National Forest, California. Aquat. Bot. 30:109-124.

Soukupova, L. 1988. Short life-cycles in two wetland sedges. Aquat. Bot. $30: 49-62$.

Steele, J.M., R.D. Ratliff, and G.L. Ritenour. 1984. Seasonal variation in total nonstructural carbohydrate levels in Nebraska sedge. J. Range Manage. 37:465-467.

Wood, S.H. 1975. Holocene stratigraphy and chronology of mountain meadows, Sierra Nevada, California. Ph.D. Thesis, Calif. Inst. Tech., Pasadena. 